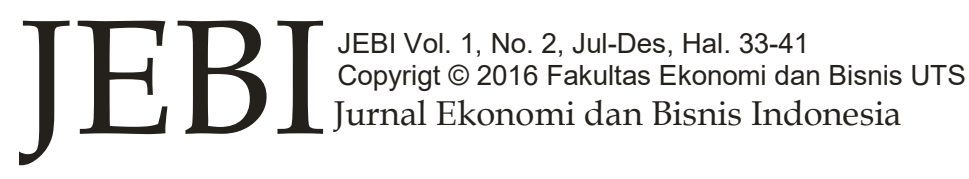

\title{
ANALISIS SUMBER- SUMBER PERTUMBUHAN EKONOMI DAN KETIMPANGAN WILAYAH DI PROVINSI NUSA TENGGARA BARAT
}

\author{
Analysis of Economic Growth Sources and Regional Disparities in West Nusa Tenggara Province
}

\author{
Fitriah Permata Cita ${ }^{1}$ \\ ${ }^{1}$ Program Studi Ekonomi Pembangunan, Fakultas Ekonomi dan Bisnis Universitas Teknologi Sumbawa \\ *) e-mail: fitriahpermatacita@yahoo.co.id
}

Tanggal Diterima: 14 September 2016

\begin{abstract}
This research aims to describe the structural and change pattern of sectoral growth in economics. This research also designed to determine the economic leading sectors in West Nusa Tenggara Provinse which could be a consideration for policy makers to make development planning. Besides that, this research could be use to understand the pattern of regional disparities and describe the factors that affect regional disparities in West Nusa Tenggara Province. This research is using Shift Share Analysis and Theil Index. The research result revealed that there were no economic sectors which have faster growth compare to the same sector in national level base on National Share (N) value. Meanwhile base on the Proportional Shift (P), there were negative value and positive value as well. The Differential Shift value without oil and natural gasses sector revealed that there were no economic sectors which growth faster compare to the same sector in national level. Furthermore, Theil Index without oil and natural gasses sector showed the very equal result. However, if oil and natural gasses included, the Theil Index value became almost 1 which mean that it was very unequal.
\end{abstract}

Keywords: Economic sources, Regional disparities, Shift share, Theil index

\begin{abstract}
ABSTRAK
Penelitian ini menggambarkan struktur dan pola perubahan pertumbuhan sektoral dalam perekonomian. Penelitian ini juga di desain untuk menentukan sektor-sektor unggulan sehingga dapat dijadikan pertimbangan dalam perumusan kebijakan dan perencanaan pembangunan di Nusa Tenggara Barat (NTB). Selain itu penelitian ini juga dapat digunakan untuk melihat besarnya ketimpangan serta faktor yang menyebabkan terjadinya ketimpangan antar wilayah di provinsi NTB. Alat analisa yang di gunakan dalam penelitian ini adalah shift share dan Indeks Theil. Hasil penelitian menunjukkan bahwa dalam nilai National Share (N) tidak terdapat sektor-sektor ekonomi yang tumbuh lebih cepat dibandingkan sektor-sektor ekonomi yang sama di tingkat Nasional. Sementara itu berdasarkan Proportional Shift $(P)$ terdapat sektor yang memiliki nilai negatif dan ada pula yang bernilai positif. Nilai Differential Shift tanpa migas menunjukkan tidak terdapat sektor-sektor ekonomi yang tumbuh lebih cepat dibandingkan sektor-sektor ekonomi yang sama di tingkat Nasional. Hasil Indeks Theil tanpa migas menunjukkan sangat merata. Namun apabila dengan migas menunjukkan nilai indeks Theil nya mendekati 1 yang berarti sangat timpang.
\end{abstract}

Kata Kunci : Sumber-sumber ekonomi, Ketimpangan wilayah, Shift share, Indeks Theil

\section{Pendahuluan}

Perekonomian suatu daerah dipengaruhi oleh sumber daya manusia dan sumber daya alam yang dimiliki oleh daerah bersangkutan. Potensi sumber daya alam yang dimiliki oleh masing-masing kabupaten/kota di Provinsi NTB relatif berbeda-beda. Hal tersebut secara tidak langsung mempengaruhi kondisi perekonomian di masing-masing kabupaten/kota. Untuk mengetahui perkembangan dan potensi ekonomi di 10 (sepuluh) kadupaten/kota Provinsi NTB, dapat dilakukan dengan membandingkan PDRB yang dicapai masingmasing kabupaten/kota.

Kabupaten/kota yang berada di wilayah Pulau Lombok umumnya memiliki PDRB lebih tinggi dibandingkan dengan kabupaten/kota yang berada di Pulau Sumbawa. Hal tersebut disebabkan oleh kondisi geografis dan sumber daya manusia yang berbeda antara Pulau Lombok dengan Pulau Sumbawa. 
Keberadaan pusat pemerintahan juga mendukung perkembangan perekonomian di Pulau Lombok dibandingkan dengan Pulau Sumbawa. Kondisi tersebut terlihat dari nilai PDRB Kabupaten Lombok Barat, Lombok Tengah, Lombok Timur dan Kota Mataram di atas Rp 3 trilyun, di tahun 2010.

Apabila dibandingkan antar kabupaten/kota maka, Kabupaten Sumbawa Barat memiliki PDRB tertinggi diantara Sementara itu laju pertumbuhan ekonomi PDRB kabupaten/kota di Provinsi NTB secara umum mengalami pertumbuhan yang positif selama 11 tahun yaitu periode 20002010. Kabupaten Sumbawa Barat (KSB) memiliki pertumbuhan yang berfluktuasi, pergerakan tersebut sangat dipengaruhi oleh turun naiknya produksi tambang non migas yang berada di wilayah kabupaten tersebut. Pada tahun 2010, Kabupaten/kota yang mengalami pertumbuhan paling tinggi adalah KSB dengan laju pertumbuhan 12,46 persen. Sedangkan kabupaten/kota yang memiliki laju pertumbuhan terendah adalah Kabupaten Lombok Utara yakni sebesar 4,32 persen.

Nilai tambah sub sektor tambang non migas mempunyai kontribusi yang cukup besar terhadap penciptaan PDRB Provinsi NTB. Jika nilai tambah sub sektor pertambangan dikeluarkan dari komponen PDRB Kabupaten Sumbawa Barat maka akan terlihat perbedaan yang cukup signifikan. PDRB tanpa pertambangan non migas maka terlihat Kabupaten yang mempunyai PDRB tertinggi pada tahun 2010 adalah Kabupaten Lombok Timur yaitu mencapai Rp 6,22 trilyun. Sedangkan Kabupaten Sumbawa Barat tanpa nilai tambah sub sektor pertambangan non migas hanya memiliki PDRB sebesar Rp 938,08 milyar sekaligus sebagai PDRB kabupaten/kota terendah di Provinsi NTB tahun 2009. Selain itu jika dilihat laju pertumbuhan ekonominya, maka tidak tampak adanya fluktuasi yang tajam sejak 2006 sampai tahun 2010 atau dengan kata lain laju pertumbuhan Kabupaten Sumbawa Barat relatif stabil.

Perbedaaan tingkat pertumbuhan dan pembangunan wilayah akan membawa dampak pada perbedaan tingkat kesejahteraan antar daerah, yang pada akhirnya justru akan menyebabkan ketimpangan regional antar daerah semakin besar. Pertumbuhan dan pelaksanaan pembangunan yang tidak merata justru akan semakin menghambat pertumbuhan wilayah yang relatif tertinggal akan semakin tertinggal.

Dengan seluruh kondisi di atas, maka timbul pertanyaan apakah perubahan kontribusi sektoral yang terjadi telah di dasarkan kepada strategi kebijakan pembangunan yang tepat sehingga dapat mengurangi ketimpangan yang terjadi antar wilayah, yaitu strategi yang memberikan dampak yang optimal bagi pertumbuhan ekonomi, peningkatan lapangan pekerjaan dan peningkatan kesejahteraan penduduk. Karena untuk melaksanakan pembangunan dengan sumber daya yang terbatas sebagai konsekuensinya harus difokuskan kepada pembangunan sektor-sektor yang memberikan dampak pengganda (multiplier effect) yang besar terhadap sektor-sektor lainnya atau perekonomian secara keseluruhan.

Berdasarkan uraian di atas, dapat di rumuskan tujuan penelitian sebagai berikut: kabupaten/kota yang lain. Pada tahun 2010 PDRB Kabupaten Sumbawa Barat mencapai Rp 17,96 triliun, lebih tinggi dibandingkan dengan tahun 2009 yang mencapai Rp 15,86 triliun. Sedangkan kabupaten/kota yang memiliki PDRB terendah adalah Kota Bima yaitu mencapai Rp 999,86 milyar.

1. Untuk mengetahui pertumbuhan ekonomi di Provinsi NTB selama periode 2000-2010 tumbuh akibat adanya pertumbuhan secara nasional

2. Untuk mengetahui pertumbuhan ekonomi Provinsi NTB selama periode 2000-2010 tumbuh akibat adanya pertumbuhan secara domestik

3. Untuk mengetahui besarnya ketimpangan yang terjadi di provinsi NTB pada tahun 2010

4. Untuk mengetahui penyebab ketimpangan antar wilayah di Provinsi NTB.

\section{Metode Penelitian}

Penelitian ini menggunakan metode deskriptif, yaitu jenis penelitian yang meneliti status kelompok manusia, suatu obyek, suatu set kondisi, suatu pemikiran ataupun suatu kelas peristiwa pada masa sekarang dengan tujuan untuk membuat gambaran ataupun lukisan secara sistematis, faktual mengenai fakta-fakta, sifat-sifat serta hubungan antar fenomena yang diselidiki (Nazir, 2005:63). Penelitian ini dilakukan untuk menganalisis sumber-sumber pertumbuhan ekonomi dan ketimpangan regional di provinsi NTB dengan pendekatan kuantitatif.

Data dalam penelitian ini bersumber dari data sekunder yaitu data yang diperoleh peneliti dari lembaga yang menjadi objek penelitian secara resmi dalam bentuk tertulis atau dokumendokumen. Dalam hal ini lembaga yang dijadikan sumber data sekunder adalah Badan Pusat Statistik (BPS). Adapun teknik pengumpulan data yang digunakan dalam penelitian ini adalah dokumentasi yaitu teknik pengumpulan data dengan jalan mencatat data-data yang dupublikasikan pada kantor atau instansi yang terkait dengan masalah yang diteliti.

Untuk menganalisa data yang telah dikumpulkan dipergunakan analisis shift share. Dengan demikian maka pertumbuhan ekonomi dan pergeseran struktural perekonomian wilayah Provinsi NTB ditentukan oleh tiga komponen, yaitu:

1. National Share (NS), yang digunakan untuk mengetahui pertumbuhan atau pergeseran struktur perekonomian di provinsi NTB dengan melihat nilai PDRB di propinsi NTB sebagai daerah pengamatan pada periode awal yang dipengaruhi oleh pergeseran pertumbuhan perekonomian Nasional. Hasil perhitungan National Share akan menggambarkan peranan Nasional yang mempengaruhi pertumbuhan perekonomian provinsi NTB. Jika pertumbuhan propinsi NTB sama dengan pertumbuhan Nasioanl maka peranannya terhadap provinsi tetap.

2. Proportional Shift $(\mathrm{P})$ adalah pertumbuhan nilai tambah bruto suatu sektor i pada provinsi NTB dibandingkan total sektor di tingkat Nasional

3. Differential Shift (D) adalah perbedaan antara pertumbuhan ekonomi di propinsi NTB dan nilai tambah bruto sektor yang sama di tingkat Nasional. 
Analisis Shift Share dapat pula dilakukan untuk mengetahui penyebab terjadinya ketimpangan wilayah. Menggunakan cara ini akan dapat diketahui pakah penyebab ketimpangan tersebut berasal dari luar daerah (National Share), atau dari dalam daerah sendiri (Proprtional Shifft dan Differential Shift). Secara matematis, Provincial Share (PS), Proportional Shift (P), dan Differential Shift (D) dapat diformulasikan sebagai berikut (Tarigan, 2005: 88; Sjafrizal, 2008:91):

1. Provincial Share $\left[\mathrm{yi}\left(\mathrm{Y}^{\mathrm{t}} / \mathrm{Y}^{0}-1\right)\right]$

2. Proportional Shift $\left[\mathrm{yi}\left(\mathrm{Y}_{\mathrm{i}}^{\mathrm{t}}-\mathrm{Y}_{\mathrm{i}}^{0}\right)-\left(\mathrm{Y}^{\mathrm{t}} / \mathrm{Y}^{0}\right)\right.$

3. Differential Shift $\left[\mathrm{y}_{\mathrm{i}}\left(\mathrm{y}_{\mathrm{i}} / \mathrm{y}_{\mathrm{i}}{ }^{0}\right)-\left(\mathrm{Y}_{\mathrm{i}}^{\mathrm{t}} / \mathrm{Y}_{\mathrm{i}}{ }^{0}\right)\right]$

$$
\begin{aligned}
& \Delta y_{\mathrm{i}}=\mathrm{y}_{\mathrm{i}}\left[\left(\mathrm{Y}^{\mathrm{t}} / \mathrm{Y}^{0}-1\right)\right]+\mathrm{y}_{\mathrm{i}}\left[\left(\mathrm{Y}_{\mathrm{i}}^{\mathrm{t}} / \mathrm{Y}_{\mathrm{i}}^{0}\right)-\left(\mathrm{Y}^{\mathrm{t}} / \mathrm{Y}^{0}\right)\right]+ \\
& \mathrm{yi}_{\mathrm{i}}\left[\left(\mathrm{yi}_{\mathrm{i}}^{\mathrm{t} / \mathrm{y}^{0}}{ }^{0}\right)-\left(\mathrm{Yi}_{\mathrm{i}}^{\mathrm{t} / \mathrm{Y}_{\mathrm{i}}^{0}}\right)\right]
\end{aligned}
$$

dimana:

$$
\begin{aligned}
\Delta y_{\mathrm{i}}= & \text { Perubahan nilai tambah sektor } \mathrm{i} . \\
\mathrm{y}_{\mathrm{i}}{ }^{\mathrm{N}}= & \text { Nilai tambah sektor } \mathrm{i} \text { ditingkat daerah pada } \\
& \text { tahun awal periode } \\
\mathrm{y}_{\mathrm{i}}^{\mathrm{t}}= & \text { Nilai tambah sektor } \mathrm{i} \text { ditingkat daerah pada } \\
& \text { tahun akhir periode. } \\
\mathrm{Y}_{\mathrm{i}}{ }^{0} \quad= & \text { Nilai tambah sektor } \mathrm{i} \text { di tingkat propinsi pada } \\
& \text { awal periode } \\
\mathrm{Y}_{\mathrm{i}}^{\mathrm{t}}= & \text { Nilai tambah sektor } \mathrm{i} \text { di tingkat propinsi pada } \\
& \text { akhir periode }
\end{aligned}
$$

\section{Theil Index ( $\left.\mathbf{T}_{d}\right)$}

Entropi Theil digunakan untuk mengukur ketimpangan yang terjadi di Propinsi Nusa Tenggara Barat dengan formulasi sebagai berikut:

$\mathrm{T}_{\mathrm{d}}=\left(\mathrm{y}_{\mathrm{ij}} / \mathrm{Y}\right) \log \left(\mathrm{y}_{\mathrm{ij}} / \mathrm{Y} / \mathrm{n}_{\mathrm{ij}} / \mathrm{N}\right)$

dimana:

$y_{i j}=$ PDRB perkapita kabupaten i di propinsi $\mathrm{j}$

$\mathrm{Y}=$ Jumlah PDRB perkapita seluruh propinsi $\mathrm{j}$

$\mathrm{N}=$ Jumlah penduduk kabupaten i di propinsi $\mathrm{j}$

$\mathrm{N}=$ Jumlah penduduk seluruh kabupaten

Bila Td mendekati 1 berarti sangat timpang dan bila $\mathrm{Td}$ mendekati nol berarti sangat merata.

Analisis Shift Share di Provinsi Nusa Tenggara Barat tahun 2000-2010

Analisis Shift Share digunakan untuk mengetahui proses pertumbuhan ekonomi Provinsi NTB dikaitkan dengan perekonomian nasional yang menjadi referensi, yaitu Indonesia. Analisis Shift Share dalam penelitian ini menggunakan variabel pendapatan, yaitu PDRB untuk menguraikan pertumbuhan ekonomi Provinsi Nusa Tenggara Barat.

Pertumbuhan PDRB total (Y) dapat diuraikan menjadi komponen shift dan komponen share, yaitu:

a. Komponen National Share (NS) adalah banyaknya pertambahan PDRB Provinsi Nusa Tenggara Barat seandainya pertumbuhannya sama dengan laju pertumbuhan PDB Indonesia selama periode studi. b. Komponen Proportional Shift (P), mengukur besarnya net shift yang diakibatkan oleh komposisi sektor-sektor PDRB Provinsi Nusa Tenggara Barat yang berubah. Apabila P > 0 , artinya Provinsi Nusa Tenggara Barat berspesialisasi pada sektor-sektor yang pada tingkat Indonesia tumbuh relatif cepat dan apabila $\mathrm{P}<0$, berarti Provinsi Nusa Tenggara Barat berspesialisasi pada sektor-sektor di tingkat Indonesia pertumbuhannya lebih lambat atau sedang menurun.

c. Komponen Differential Shift (D), mengukur besarnya net shift yang diakibatkan oleh sektor-sektor tertentu yang tumbuh lebih cepat atau lebih lambat di Provinsi Nusa Tenggara Barat dibandingkan dengan Indonesia yang disebabkan oleh faktor-faktor lokasional intern, seperti sumber daya yang baik akan mempunyai Differential Shift Component positif (D >0), sebaliknya apabila secara lokasional tidak menguntungkan akan mempunyai Differential Shift Component yang negatif $(\mathrm{D}<0)$.

Pertumbuhan komponen National Share Provinsi Nusa Tenggara Barat selama periode tahun 2000-2004 (dengan tambang) semua bernilai postif yang artinya bahwa pertumbuhan di tingkat nasional lebih cepat dibandingkan di propinsi Nusa Tenggara Barat. Ini berarti bahwa peningkatan kegiatan ekonomi Provinsi Nusa Tengara Barat akibat kebijaksanaan nasional yang berlaku.

Pertumbuhan komponen Proportional Shift propinsi Nusa Tenggara Barat selama periode tahun 2000-2004 (dengan tambang) ada yang bernilai positif ada yang bernilai negatif. Nilai $\mathrm{P}$ positif, berarti perekonomian Provinsi NTB berspesialisasi pada sektor yang sama yang tumbuh cepat pada perekonomian Indonesia. Sebaliknya apabila nilai $\mathrm{P}$ negatif, berarti perekonomian Provinsi NTB berspesialisasi pada sektor yang sama dan tumbuh lambat pada perekonomian Indonesia.

Sektor dan sub sektor yang memiliki nilai komponen proporsional positif, yaitu sub sektor peternakan dan hasilhasilnya sebesar $181.027,33$, sub sektor perikanan yaitu sebesar 292.949,51, kedua sub sektor ini yang memberikan sumbangan yang berarti terhadap proportional shift sektor pertanian karena sub sektor peternakan dan perikanan ini merupakan program pemerintah propinsi NTB yaitu Bumi Sejuta Sapi sehingga sub sektor ini terus dikembangkan walaupun sektor pertanian memiliki nilai proportional shift negative yang artinya bahwa pertumbuhan sub sektor peternakan dan sub sektor perikanan berspesialisasi pada sektor yang memiliki pertumbuhan yang cepat yang terjadi di nasional. Proportional share yang bernilai positif ini terutama disebabkan karena tingginya sumbangan sektor pertambangan dan penggalian terhadap pembentukan PDRB sehingga menyebabkan proportional share bernilai positif yaitu sebesar 376.269,22, hal ini disebabkan karena beroperasi nya PT Newmont di kabupaten Sumbawa Barat.

Sedangkan sektor-sektor yang mempunyai nilai komponen proporsional negatif, yaitu sektor pertanian sebesar 6.621.482,77 sub sektor kehutanan sebesar -101.477,58 dan sub sektor tanaman bahan makanan sebesar 1.146.149,89, sub sektor tanaman perkebunan sebesar - 
238.974,02 yang artinya bahwa sektor dan sub sektor ini memiliki pertumbuhan yang lambat dibandingkan di tingkat nasional karena sektor ini tidak berspesialisasi secara nasional tumbuh lebih lambat, selanjutnya sektor listrik, gas dan air bersih, sub sektor listrik, sub sektor air bersih yaitu sebesar -82.651 .83 . Hal ini disebabkan karena masih ada daerah di propinsi NTB yang belum mendapatkan pelayanan listrik, gas dan air bersih karena daerah topografi daerah yang berbukit sehingga menyebabkan akses sektor listrik, gas dan air bersih ini suli terutama di wilayah Kabupaten Lombok Utara.

Sektor-sektor yang memiliki nilai komponen pertumbuhan proporsional positif, yaitu sub sektor penggalian sebesar 39.212,74 sektor listrik, gas dan air bersih yaitu sebesar 10.723 hal ini disebabkan bahwa pada periode 2005-2010 sektor ini semakin banyak diminati oleh masyarakat NTB. Selanjutnya sektor bangunan yaitu sebesar $130.548,91$ hal ini dapat dijelaskan dari meningkatnya infrastruktur pemerintah maupun swasta. Keadaan ini menunjukkan suatu perkembaangan nyata dimana pada pada masa otonomi daerah pemerintah propinsi Nusa Tenggara Barat sedang giat membangun infrastrukur terutama untuk menunjang pendidikan, kesehatan, dan pelayanan umum di bangun di daerah yang baru mekar. Selain itu wilayah perkotaan pihak swasta banyak mendirikan bangunan usaha.

Sektor perdagangan, hotel dan restoran, sub sektor perdagangan, besar dan eceran, sub sektor restoran yaitu sebsar 88.683, peningkatan pertumbuhan sektor perdagangan, hotel dan restoran ini juga disebabkan karena pemerintah pusat menetapkan propinsi NTB sebagai wilayah masterplan dengan pengembangan sektor pariwisata sehingga sektor perdagangan, hotel dan restoran ini meningkat begitu juga dengan sektor pengangkutan dan komunikasi yang nilai pertumbuhan proportionalnya positif yautu sebesar 737.976,45 sub sektor angkutan udara, sub sektor komunikasi sebesar 354.552,848, sektor keuangan, persewaan dan jasa-jasa perusahaan sebesar 32.684,64 yang disebabkan karena meningkatnya sub sektor keuangan lembaga keuangan bukan bank, sub sektor sewa bangunan, sub sektor jasa perusahaan, sektor jasa-jasa, sub sektor swasta, sub sektor sosial kemasyarakatan, sub sektor hiburan dan rekreasi, sub sektor perorangan dan rumah tangga.

Sedangkan sektor-sektor yang mempunyai nilai komponen pertumbuhan proporsional negatif, yaitu sektor pertanian, dan perikanan, sub sektor tanaman bahan makanan, sub sektor tanaman perkebunan, sektor peternakan, sub sektor kehutanan, sub sektor perikanan, sektor sektor pertambangan tanpa migas, sektor industri pengolahan, sub sektor industri tanpa migas, sub sektor makanan, minuman, dan tembakau, sub sektor tekstil, barang kulit dan alas kaki, sub sektor barang kayu dan hasil lainnya, sub sektor kertas dan barang cetakan sub sektor pupuk, kimia dan barang karet, sub sektor logam dasar besi dan baja, sub sektor barang lainnya, sub sektor air bersih, sektor bangunan, sub sektor hotel, sub sektor pengangkutan, sub sektor pengangkuatan, sub sektor angkuatn jalan raya, sub sektor angkutan laut, sub sektor angkutan sungai, sub sektor jasa penunjang angkutan,sub sektor bank sub sektor pemerintahan umum, sub sektor admininstrasi, pemerintahan dan pertahanan. Hal ini disebabkan karena sektor tersebut memiliki pertumbuhan yang lambat dan berspesialisasi pada sektor yang tumbuh dengan lambat bahkan sedang merosot.

Nilai Differential Shift (D) sektor perekonomian Provinsi NTB selama periode tahun 2005-2010 (dengan tambang) ada yang memiliki nilai negatif dan nilai positif sub sektornya. Nilai D negatif, berarti sektor tersebut tumbuh lebih lambat dibandingkan sektor yang sama di Indonesia. Sedangkan nilai D yang positif berarti sektor tersebut tumbuh lebih cepat dibandingkan sektor yang sama yang ada di Indonesia.

Sektor-sektor yang memiliki nilai Differential Shift (D) positif adalah sub sektor peternakan dan hasil-hasilnya yaitu sebesar 24.440,38 , sektor pertambangan dan penggalian sebesar $736.025,13$. sektor industri pengolahan sebesar 119.515.75 sub sektor industri tanpa migas sebesar $99.168,76$, sub sektor makanan, minuman, dan tembakau, sub sektor tekstil, barang kulit dan alas kaki, sub sektor barang kayu dan hasil hutan lainnya, sub sektor kertas dan barang cetakan, sub sektor pupuk, kimia, dan barang dari karet, sub sektor logam dasar besi dan baja, sub sektor barang lainnya yang merupakan komponen dari sektor industry pengoalahan, sub sektor listrik, gas dan air bersih yaitu sebesar 4.091,05, sektor bangunan yaitu sebesar $28.633,80$ sektor perdagangan, hotel dan restoran yaitu sebesar 123.666,58 dan semua sub sektor nya juga memiliki niali differential shift yang positif yaitu sub sektor perdagangan besar dan eceran, sub sektor hotel, sub sektor restoran, sektor pengangkutan yang memiliki nilai differential yang positif yaitu sub sektor angkutan laut sebesar 4.684,08 sub sektor angkutan sungai danau dan penyeberangan sebesar $8.817,46$ sub sektor angkutan udara sebesar 17.190,29 sub sektor jasa penunjang angkutan sebesar 3.688,86 sektor keuangan persewaan dan jasa perusahaan yang mencakup sub sektor bank, sektor jasa-jasa, sub sektor pemerintahan umum, sub sektor pemerintahan umum, sub sektor administrasi pemerintahan dan pertahanan yaitu sebesar 80.194,03. Hal ini berarti bahwa sektor dan sub sektor tersebut tumbuh lebih cepat di propinsi NTB dibandingkan di tingkat nasional.

Sedangkan sektor dan sub sektor yang memiliki nilai D negatif adalah sektor pertanian, peternakan, kehutanan, dan perikanan, sub sektor tanaman bahan makanan, sub sektor tanaman perkebunan, sub sektor perikanan yaitu sebesar -141.925,15 sub sektor pertambangan tanpa migas sebesar -6.185.64 sub sektor penggalian sebesar $13.404,80$ sektor pengangkutan dan komunikasi yaitu sebsar $-690.407,54$ sub sektor angkutan jalan raya sebesar $-7.438,55$ sub sektor komunikasi sebesar $-308.539,17 \mathrm{sub}$ sektor lembaga keuangan bukan bank sebesar $-6.320,83$ sub sektor sewa bangunan sebesar $-9.033,07$ sub sektor 
jasa perusahaan, sebesar $-1.786,12$ sub sektor swasta sebesar -17.756,62 sub sektor sosial kemasyarakatan $8.384,48$ sosial hiburan dan rekreasi sebesar $-560,41 \mathrm{sub}$ sektor perorangan dan rumah tangga sebesar 3.679,25. Hal ini berarti bahwa sektor dan sub sektor tersebut memiliki pertumbuhan yang lambat di tingkat nasional.

Sedangkan komponen proportional Provinsi NTB selama periode tahun 2004-2005 (tanpa tambang) ada yang bernilai negatif dan positif. Nilai $P$ positif, berarti perekonomian Provinsi NTB berspesialisasi pada sektor yang sama yang tumbuh cepat pada perekonomian Provinsi Indonesia. Sebaliknya apabila nilai $\mathrm{P}$ negatif, berarti perekonomian Provinsi Nusa Tenggara Barat berspesialisasi pada sektor yang sama dan tumbuh lambat pada perekonomian Indonesia.

Sektor-sektor yang memiliki nilai komponen pertumbuhan proporsional positif pada tahun 2004-2005 (tanpa tambang) yaitu sub sektor perikanan, sektor industri pengolahan, sub sektor industri tanpa migas, sub sektor tekstil, sub sektor barang kulit dan alas kaki, sub sektor barang kayu dan hasil hutan, sub sektor semen dan barang galian bukan logam, sub sektor alat angkutan mesin dan peralatan, sektor perdagangan, hotel dan restoran, sub sektor perdagangan besar dan eceran, sub sektor hotel, sub sektor angkutan udara, sub sektor komunikasi, sektor keuangan, persewaan dan jasa perusahaan, sub sektor bank, sub sektor sewa bangunan, sub sektor jasa perusahaan, sub sektor swasta, sub sektor social kemasyarakatan, sub sektor hiburan dan rekreasi, sub sektor perorangan dan rumah tangga. Hal ini berarti bahwa Hal ini berarti bahwa sektor dan sub sektor tersebut tumbuh lebih cepat di propinsi NTB dibandingkan di tingkat nasional.

Sedangkan sektor dan sub sektor yang memiliki nilai negatif pada tahun 2004-2005 (tanpa tambang) yaitu sektor pertanian, peternakan, kehutanan, dan perikanan, sub sektor tanaman bahan makanan, sub sektor tanaman perkebunan, sub sektor kehutanan, sektor pertambangan dan penggalian, sub sektor penggalian, sub sektor kertas, dan barang cetakan, sub sektor logam dasar besi \& baja, sektor listrik, gas dan air bersih, sub sektor listrik, sub sektor air bersih, sektor bangunan, sub sektor restoran, sektor pengangkutan dan komunikasi, sub sektor pengangkutan, sub sektor angkutan jalan raya, sub sektor angkutan angkutan laut, sub sektor angkutan sungai, sub sektor jasa penunjang angkutan, sub sektor lembaga keuangan bukan bank, sub sektor pemerintahan umum, sub sektor adm pembangunan, sub sektor jasa pemerintahan lainnya. Hal ini berarti bahwa sektor dan sub sektor tersebut tumbuh lebih lambat di propinsi NTB dibandingkan di tingkat nasional.

Nilai Differential Shift perekonomian Provinsi NTB tanpa migas dari tahun 2004-2005 (tanpa tambang) menunjukkan tidak terdapat sektor-sektor ekonomi yang tumbuh lebih cepat dibandingkan sektor-sektor ekonomi yang sama di tingkat Indonesia.
Pertumbuhan komponen pertumbuhan National Share Provinsi NTB selama periode tahun 2005-2010 (tanpa tambang) semua bernilai postif yang artinya bahwa pertumbuhan di tingkat nasional lebih cepat dibandingkan di propinsi NTB. Ini berarti bahwa peningkatan kegiatan ekonomi Provinsi NTB akibat kebijaksanaan nasional yang berlaku.

Sedangkan komponen proportional Provinsi NTB selama periode tahun 2005-2010 (tanpa tambang) ada yang bernilai negatif dan positif. Nilai $P$ positif, berarti perekonomian Provinsi NTB berspesialisasi pada sektor yang sama yang tumbuh cepat pada perekonomian Provinsi Indonesia. Sebaliknya apabila nilai $\mathrm{P}$ negatif, berarti perekonomian Provinsi NTB berspesialisasi pada sektor yang sama dan tumbuh lambat pada perekonomian Indonesia.

Sektor dan sub sektor yang memiliki nilai komponen pertumbuhan proporsional positif pada tahun 2005-2010 (tanpa tambang) yaitu sektor pertambangan dan penggalian, sub sektor penggalian, sub sektor semen dan barang galian bukan logam, sub sektor alat angkutan mesin, sektor listrik, gas dan air bersih, sub sektor listrik, sektor bangunan, sektor perdagangan, hotel dan restoran, sektor perdgangan besar dan aceran, sektor penganngkutan dan komunikasi, sub sektor angkutan udara, sub sektor komunikasi, sektor keuangan, persewaan dan jasa perusahaan, sub sektor lembaga keuangan bukan bank, sub sektor sewa bangunan, sub sektor jasa perusahaan, sektor jasa-jasa, sub sektor swasta, sub sektor social kemasyarakatan, sub sektor hiburan dan rekreasi, sub sektor perorangan dan rumah tangga. Hal ini berarti bahwa perekonomian Provinsi NTB berspesialisasi pada sektor yang sama yang tumbuh cepat pada perekonomian Indonesia.

Sedangkan sektor dan sub sektor yang memiliki nilai komponen pertumbuhan proporsional negatif pada tahun 2005-2010 (tanpa tambang) yaitu yaitu sektor pertanian, peternakan, kehutanan, dan perikanan, sub sektor tanaman bahan makanan, sub sektor tanaman perkebunan, sub sektor kehutanan, sektor pertambangan dan penggalian, sub sektor penggalian, sub sektor kertas, dan barang cetakan, sub sektor logam dasar besi \& baja, sektor listrik, gas dan air bersih, sub sektor listrik, sub sektor air bersih, sektor bangunan, sub sektor restoran, sektor pengangkutan dan komunikasi, sub sektor pengangkutan, sub sektor angkutan jalan raya, sub sektor angkutan angkutan laut, sub sektor angkutan sungai, sub sektor jasa penunjang angkutan, sub sektor lembaga keuangan bukan bank, sub sektor pemerintahan umum, sub sektor adm pembangunan, sub sektor jasa pemerintahan lainnya. Hal ini berarti bahwa sektor dan sub sektor tersebut tumbuh lebih lambat di propinsi NTB dibandingkan di tingkat nasional.

Nilai Differential Shift perekonomian Provinsi NTB tanpa migas dari tahun 2005-2010 (tanpa tambang) menunjukkan tidak terdapat sektor-sektor ekonomi yang tumbuh lebih cepat dibandingkan sektor-sektor ekonomi yang sama di tingkat Indonesia. Hal ini ditunjukkan dengan nilai 
differential Shift dari masing sektor dan sub sektor bernilai negative disebabkan karena pada tahun 2009/2010 terjadi krisis financial sehingga masing-masing sektor dan sub sektor sedikit memberikan kontribusi terhadap pembentukan PDRB di Provinsi NTB.

\section{Analisis Ketimpangan Wilayah di Provinsi NTB}

Kesenjangan yang sering terjadi adalah kesenjangan ekonomi dan kesenjangan indikator pendapatan. Hal ini terjadi pada semua negara, baik negara maju maupun Negara berkembang. Suatu hal yang wajar dalam suatu Negara apabila terdapat beberapa daerah atau wilayah terbelakang dari wialayah lainnya, yang disebabkan oleh perbedaan potensi yang dimiliki oleh masing-masing wilayah. Pada umumnya kesenjangan antar wilayah lebih besar terjadi pada Negara yang sedang berkembang karena pembangunan yang dilakukan lebih mengarah pada proses pertumbuhan dan jarang memperhatikan pemerataan.

Untuk mengukur ketimpangan wilayah di Provinsi NTB di gunakan Indeks Theil. Data yang diperlukan dalam analisis ini adalah data PDRB masing-masing kabupaten/ kota di Provinsi NTB, data PDB Indonesia, jumlah penduduk masing-masing kabupaten/kota di Provinsi Nusa Tenggara Barat, jumlah penduduk Indonesia dengan priode waktu dari tahun 2000 sampai dengan 2010. Penafisran dalam indeks theil yaitu apabila nilai indeks theil nya mendekati 1 artinya sangat timpang dan sebaliknya apabila indeksnya mendekati 0 berarti sangat merata.

Nilai Indeks Theil Provinsi NTB berfluktuasi dari tahun ke tahun dimana pada tahun 2000 nilai indeks theilnya sebesar 0,116 menunjukkan bahwa Provinsi NTB sangat merata, tahun 2001 sebesar 0,114 juga sangat merata, tahun 2003 sebesar -0,01 yang berarti bahwa Provinsi NTB pada tahun 2003 sangat merata, tahun 2004 sebesar 0,268 masih dalam penafsiran merata, namun pada tahun 2005 nilai indeks theil Provinsi NTB yaitu sebesar 0,928 yaitu mendekati 1 yang berarti sangat timpang. Hal ini disebabkan karena telah beroperasinya PT Newmont di Kabupaten Sumbawa Barat sehingga sektor pertambangan dan penggalian memiliki kontribusi terbesar terhadap pembentukan PDRB sehingga menyebabkan ketimpangan wilayah di Provinsi Nusa Tenggara Barat, namun apabila tanpa migas nilai indeks theilnya yaitu sebesar 0,014 yang menunjukkan sangat merata. Tahun 2006 nilai indeks theil nya yaitu sebesar 0,425 yang menunjukkan walaupun dengan sektor migas, hal ini disebabkan kerana pemerintah mengembangkan juga sektor yang lainnya selain sektor pertambangan agar tidak terjadi ketimpangan yang terlalu melebar, tahun 2006 tanpa migas nilai indeks theilnya adalah sebesar 0,082 yang menunjukkan bahwa Provinsi Nusa Tenggara Barat sangat merata. Tahun 2007 dengan migas menunjukkan sangat timpang, hal ini ditunjukkan dengan nilai indeks theil sebesar 0,818 yaitu mendekati 1 , dan ini masih di pengaruhi oleh sektor pertambangan dan penggalian yang di Kabupaten Sumbawa Barat. Sedangkan apabila tanpa migas nilai indeks theil nya yaitu sebesar 0,171 yang menunjukkan merata karena mendekati nilai 0 .
Demikian juga dengan tahun 2008, tahun 2009, dan tahun 2010 apabila dengan migas menunjukkan ketimpangan apabila tanpa migas menunjukkan sangat merata.

Dari hasil indeks theil tersebut dapat diketahui faktor penyebab dari ketimpangan wilayah yang terjadi dengan menggabungkan alat analisis indeks theil dan alat analisis Shift Share yaitu apakah penyebab ketimpangan yang terjadi Provinsi NTB berasal dari luar daerah (National Share), atau dari dalam daerah sendiri ( Proportional Shift dan Differential Shift ). Dari hasil perhitungan Shift Share yang dapat dilihat pada lampiran 2 dengan migas dengan kurun waktu 2000 sampai dengan 2004 ketimpangan terjadi disebabkan karena dari dalam daerah itu sendiri dalam hal ini adalah Provinsi NTB, hal ini ditunjukkan dengan nilai proportional shift dan dan differential shift masing-masing sector dan sub sektor nya menunjukkan nilai negatif sedangkan nilai national share nya menunjukkan nilai positif, begitu juga pada tahu 2005 sampai dengan tahun 2010 ketimpangan yang terjadi di Provinsi NTB disebabkan karena dari dalam daerah itu sendiri dimana nilai proportional shift dan differential shift menunjukkan nilai negatif.

\section{Kesimpulan}

1.

ilai National Share (N) perekonomian Provinsi NTB periode 2000-2010 (dengan dan tanpa tambang) menunjukkan tidak terdapat sektor-sektor ekonomi di propinsi NTB yang tumbuh lebih cepat dibandingkan sektor-sektor ekonomi yang sama di tingkat Indonesia. Hal ini ditunjukkan dengan nilai National Share (N) dari masing sektor dan sub sektor bernilai positif yang artinya bahwa peningkatan kegiatan ekonomi propinsi NTB akibat kebijaksanaan nasional.

2.

ektor dan sub sektor yang memiliki nilai Proportional Shift $(P)$ positif adalah sub sektor peternakan dan hasilhasilnya, sub sektor kehutanan, sektor pertambangan dan penggalian, sektor industri pengolahan, sub sektor industri tanpa migas, sub sektor makanan, minuman, dan tembakau, sub sektor tekstil, barang kulit dan alas kaki, sub sektor barang kayu dan hasil hutan lainnya, sub sektor kertas dan barang cetakan, sub sektor pupuk, kimia, dan barang dari karet, sub sektor logam dasar besi dan baja, sub sektor barang lainnya, sub sektor listrik, gas dan air bersih, sub sektor listrik, sub sektor air bersih, sektor bangunan, sektor perdagangan, hotel dan restoran, sub sektor perdagangan besar dan eceran, sub sektor hotel, sub sektor restoran, sub sektor pengangkutan, sub sektor angkutan laut, sub sektor angkutan sungai, danau dan penyeberangan, sub sektor angkutan udara, sub sektor jasa penunjang angkutan, sektor keuangan, persewaan dan jasa perusahaan, sub sektor bank, sektor jasa-jasa, sub sektor pemerintahan umum, sub sektor pemerintahan umum, sub sektor administrasi pemerintahan dan pertahanan. Dan sektor dan sub sektor yang memiliki nilai $P$ negatif adalah sektor pertanian, peternakan, kehutanan, dan perikanan, sub sektor tanaman bahan makanan, sub sektor tanaman 
perkebunan, sub sektor perikanan, sub sektor pertambangan tanpa migas, sub sektor penggalian, sub sektor semen dan barang galian bukan logam, sub sektor alat angkutan mesin dan peralatan, sektor pengangkutan dan komunikasi, sub sektor angkutan jalan raya, sub sektor komunikasi, sub sektor lembaga keuangan bukan bank, sub sektor sewa bangunan, sub sektor jasa perusahaan, sub sektor swasta, sub sektor sosial kemasyarakatan, sosial hiburan dan rekreasi, sub sektor perorangan dan rumah tangga.

Nilai Differential Shift perekonomian Provinsi NTB tanpa migas dari tahun 2000-2010 menunjukkan tidak terdapat sektor-sektor ekonomi yang tumbuh lebih cepat dibandingkan sektor-sektor ekonomi yang sama di tingkat Nasional.

3.

ilai indeks theilnya tahun 2000 sebesar 0,116 , tahun 2001 sebesar 0,114, tahun 2004 sebesar 0.268 menunjukkan bahwa Provinsi NTB sangat merata, tahun 2003 sebesar 0,01 yang berarti bahwa Provinsi NTB pada tahun 2003 sangat merata, Namun pada tahun 2005 nilai indeks theil Provinsi NTB yaitu sebesar 0,928 yaitu mendekati 1 yang berarti sangat timpang. Hal ini disebabkan karena telah beroperasinya PT Newmont di Kabupaten Sumbawa Barat sehingga sektor pertambangan dan penggalian memiliki kontribusi terbesar terhadap pembentukan PDRB sehingga menyebabkan ketimpangan wilayah di Provinsi NTB.

Namun apabila tanpa migas nilai indeks theilnya yaitu sebesar 0,014 yang menunjukkan sangat merata. Tahun 2006 nilai indeks theil nya yaitu sebesar 0,425 yang menunjukkan walaupun dengan sektor migas, hal ini disebabkan kerana pemerintah mengembangka juga sektor yang lainnya selain sektor pertambangan agar tidak terjadi ketimpangan yang terlalu melebar, tahun 2006 tanpa migas nilai indeks theilnya adalah sebesar 0,082 yang menunjukkan bahwa Provinsi NTB sangat merata.

Tahun 2007 dengan migas menunjukkan sangat timpang, hal ini ditunjukkan dengan nilai indeks theil sebesar 0,818 yaitu mendekati 1 , dan ini masih di pengaruhi oleh sektor pertambangan dan penggalian yang di Kabupaten Sumbawa Barat. Sedangkan apabila tanpa migas nilai indeks theil nya yaitu sebesar 0,171 yang menunjukkan merata karena mendekati nilai 0 . Demikian juga dengan tahun 2008, tahun 2009, dan tahun 2010 apabila dengan migas menunjukkan ketimpangan apabila tanpa migas menunjukkan sangat merata.

4.

aktor penyebab dari ketimpangan wilayah yang terjadi dengan menggabungkan alat analisis indeks theil dan alat analisis Shift Share yaitu apakah penyebab ketimpangan yang terjadi di Provinsi Nusa Tenggara Barat berasal dari luar daerah ( National Share), atau dari dalam daerah sendiri ( Proportional Shift dan Differential Shift ). Dari hasil perhitungan Shift Share dengan migas dengan kurun waktu 2000 sampai dengan 2004 ketimpangan terjadi disebabkan karena dari dalam daerah itu sendiri dalam hal ini adalah Provinsi NTB, hal ini ditunjukkan dengan nilai proportional shift dan dan differential shift masing-masing sektor dan sub sektor nya menunjukkan nilai negatif sedangkan nilai national share nya menunjukkan nilai positif, begitu juga pada tahu 2005 sampai dengan tahun 2010 ketimpangan yang terjadi di Provinsi NTB disebabkan karena dari dalam daerah itu sendiri dimana nilai proportional shift dan differential shif menunjukkan nilai negatif.

\section{Saran}

1. Hasil identifikasi sektor-sektor dan sub sektor yang memiliki pertumbuhan yang positif dapat ditindak lanjuti oleh pemerintah. Dengan demikian hal ini bisa membantu pemerintah daerah melihat kekuatan atau kelemahan wilayahnya dibandingkan secara relatif dengan wilayah yang lebih luas. Potensi-potensi yang positif digunakan dalam strategi pengembangan wilayah. Adapun faktorfaktor yang membuat potensi sektor di suatu wilayah lemah perlu dipikirkan apakah perlu ditanggulangi atau dianggap tidak prioritas.

2. Hasil analisis ketimpangan antar wilayah dapat digunakan sebagai bahan masukan pemerintah daerah dan rekomendasi kebijakan serta upaya untuk menanggulangi ketimpangan pembangunan antar wilayah. Beberapa upaya yang dapat dilakukan oleh pemerintah daerah antara lain yaitu dengan memperlancar proses perdagangan dan mobilitas faktor produksi antar daerah, melalui transmigrasi atau pemindahan tenaga kerja dari daerah maju ke daerah kurang maju, melalui pengembangan pusat-pusat pertumbuhan sehingga akan dapat mengurangi ketimpangan karena adanya konsentrasi, serta melalui pelaksanaan otonomi daerah yang tegas, bertanggung jawab dan berkelanjutan.

3. Untuk mengatasi ketimpangan sektoral dan ketimpangan antar wilayah maka pemerintah daerah Propinsi NTB dan pemerintah daerah kabupaten/kota perlu mengembangkan sektor lain yang sebagai sektor yang memiliki pertumbuhan differential shift yang benilai positif yang menggantikan sektor pertambangan dan penggalian karena hasil tambang tersebut lama-lama akan habis. Dalam hal ini pemerintah daerah harus berani mengambil terobosan dalam hal peraturan daerah yang mendkung dan mendorong tumbuhnya sektor-sektor lainnya yang memiliki pertumbuhan differential shift positif.

4. Selain untuk mengatasi ketimpangan sektoral maupun ketimpangan antar wilayah yang terjadi, maka pemerintah daerah propinsi NTB fan pemerintah daerah kabupaten/kota perlu mengembangkan sektor lain sebagai sektor yang memiliki pertumbuhan differential shift yang bernilai positif untuk menggantikan sektor pertambangan dan penggalian, salah satu cara yang dilakukan yaitu dengan mengeluarkan peraturan daerah yang mendukung dan mendorong tumbuhnya sektor-sektor yang memiliki nilai differential shift positif. 


\section{Daftar Pustaka}

Adisasmita Rahardjo, 2005. Dasar-dasar Teori Wilayah.Yogyakarta: Graha Ilmu .

Alisjahbana, Akina. 2002. Analisis Ketimpangan Pendapatan Regional China dan Indonesia. ( Skripsi Sarjana tidak dipublikasikan ).

Arsyad Lincolin. 2000. Pengantar Perencanaan dan Pembangunan Ekonomi Daerah. Yogyakarta: BPFE.

Azulaidin. 2003. Analisis Pertumbuhan Ekonomi dan Ketimpangan Antar Wilayah Pembangunan di Sumatera Utara ( Thesis ). Yogyakarta. Program Pasca Sarjana Universitas Gadjah Mada ).

Badan Pusat Statistik.1999. Produk Domestik Regional Bruto. Propinsi Nusa Tenggara Barat. Mataram

Badan Pusat Statistik. 2004. Produk Domestik Regional Bruto Propinsi Nusa Tenggara Barat. Mataram

Badan Pusat Statistik. 2010. Produk Domestik Regional Bruto Propinsi Nusa Tenggara Barat. Mataram

Badrudin. 1999. Analisis Pertumbuhan di Daerah Istimewa Yogyakarta ( Skripsi Sarjana tidak dipublikasikan )

Boediono. 1988. Teori Pertumbuhan Ekonomi. Yogyakarta : BPFE.

Fachrurrazy. 2009. Analisis Penentruan sektor Unggulan Perekonomian Wilayah Kabupaten Aceh Utara dengan Pendekatan Sektor Pembentuk PDRB (Tesis). Pascasarjana Universitas Sumatera Utara Medan.

Glasson, Jhon. 1977. Pengantar Perencanaan Regional. Terjemahan Paul Sitohang. Lembaga Penerbit FE UI, Jakarta.

Jhingan,M.L.2000.Ekonomi Pembangunan dan Perencanaan.Jakarta: PT Raja Grafindo Persada.

Jhon, Blair. 1991. Urban and Regional Economics, Homewood, illinois : Irwin G.

Kristiyanti L. 2007. Analisis Sektor Basis Perekonomian dan Perananya dalam mengurangi Ketimpangan Pendapatan Antar Kabupaten/Kota di Propinsi Jawa Timur. ( Tesis ). Institut Pertanian Bogor. Fakultas Ekonomi dan Manajemen. Bogor.

Modul 4. Tipology Klassen. Retrieved from http://www.scribd.com/doc/2908449/Modul 4 Tipology Klassen

Nazir, Moh. 2005. Metodologi Penelitian. Jakarta : Ghalia Indonesia

Paul Sitohang. Edisi Revisi. Lembaga Penerbit FE UI. Jakarta

Richardson, Harry W. 2001. Dasar-dasar Ilmu Ekonomi Regional. Terjemahan Paul Sitohang. Edisi Revisis. Lembaga Penerbit FE UI. Jakarta
Sadono, Sukirno. 2000. Ekonomi Pembangunan. Jakarta : Ghalia Indonesia.

Sirojuzilan.2008. Disparitas Ekonomi dan Perencaan Regional, Ketimpangan Ekonomi Wilayah Barat dan Wilayah Timur Propinsi Sumatera Utara. Pustaka Bangsa Press.

Sjafrizal. 2002. Pertumbuhan Ekonomi dan Ketimpangan Regional Wilayah Indonesia bagian Barat. Padang: Baduose Media.

Sjafrizal, 2008.Ekonomi Regional, Teori dan Aplikasi, Baduose Media, CetakanPertama, Padang

Sudarmono, Mulyanto. 2006. Analisis Transformasi Struktural, Pertumbuhan Ekonomi dan Ketimpangan Antar Daerah di wilayah Pembangunan I Jawa Tengah. (Tesis). Program Pascasarjana Universitas Diponegoro Semarang.s

Tarigan, Robinson. 2002. Perencanaan Pembangunan Wilayah. Jakarta : PT. Bumi Aksara

Tarigan, Robinson. 2005. Ekonomi Regional Teori dan Aplikasi. Jakarta : Bumi Aksara. 